\title{
Nature of Social Intelligence of the Personality and its Basic Functions
}

\section{Природа соціального інтелекту особистості та його базові функції}

Eduard Ivashkevych

Doctor in Psychology,

Professor
Едуард Івашкевич

доктор психологічних наук, професор

E-mail:ivashkevych.e@gmail.com orcid.org/0000-0003-0376-4615

Researcher ID: V-8872-2018

Rivne State University of the Humanities, Rivne, Ukraine

12, Stepana Bandery str., Rivne, 33000

\section{Liana Onufriieva}

Ph. D. in Psychology, Assistant Professor, Professor of the Department of General and Applied Psychology, Head of the Department of General and Applied Psychology
Kamianets-Podilskyi National

Ivan Ohiienko University, Kamianets-Podilskyi, Ukraine 61 , Ohiienka street, Kamianets-Podilskyi, Khmelnytskyi region, 32300
Рівненський державний гуланітарний університет, м. Рівне, Украӥна вул. Степана Бандери, 12, м. Рівне, Україна, 33000 Ліана Онуфрієва кандидат психологічних наук, доцент, професор кафедри, завідувач кафедри загальної та практичної психології

$$
\begin{aligned}
& \text { E-mail: kpnu_lab_ps@ukr.net } \\
& \text { orcid.org/0000-0003-2442-4601 } \\
& \text { Researcher ID: R-5598-2018 }
\end{aligned}
$$


Original manuscript received February 23, 2019

Revised manuscript accepted March 19, 2019

The author's contribution: E. Ivashkevych $-50 \%$, L. Onufriieva $-50 \%$. Авторський внесок: Е. Івашкевич - 50\%, Л. Онуфрієва $-50 \%$.

\section{ABSTRACT}

In the article it was shown that social intelligence in psychology is considered as the ability of a person to understand correctly his / her own behavior and the behavior of other people in the society. This ability is very necessary for a person to have an effective interpersonal interaction and successful social adaptation. Social intelligence implements the functioning of cognitive processes associated with the reflection of a person as a partner in the processes of communication and activities. The main function of social intelligence is to predict the behavior of others.

It is emphasized that each type of intelligence contains certain abilities of the personality to perform a certain type of the activities. In this case, for example, "linguistic intelligence» is referred to as "intelligence» by the authors, because it is a complex of integral education, which includes separate abilities to perform a certain type of the activity, and if we talk about a specialist in this sphere of the activity, his / her competences, we remind about the structure of the professional competence of the person. Thus, guided by the narrow sense of understanding the word "intelligence», we distinguish: social intelligence; technical intelligence; artistic intelligence; information intelligence.

Thus, the functions of social intelligence of the person are the understanding of other people, adaptation to the requirements of the society, knowledge of the behavior of social subjects, cognitive and behavioral functions, functions of understanding the actions of other people and their influence on them, understanding themselves and modeling behavior in accordance with their needs, goals and abilities, the ability to express spontaneous judgments about other people, to predict the behavior of other people, the functions of adapting to life situations, solving practical problems and situations of everyday life, function of social adaptation, functions to solve problems at the subject-subjective level, self-organization of intelligence, socialization in the society, internalization of social norms and rules, the choice of corresponding reaction in interpersonal interaction, as well as the function of "ensuring adaptability in conditions that constantly predict the formation of a program of successful interpersonal interaction", "planning and forecasting of inter- 
personal events of the social environment», "motivational function», "the function of social competence», "self-development», "self-cognition» and "self-studying". All these functions can be combined with such generalized functions as cognitive-evaluative, communicative-value, and reflexive correction. At various stages of the performance of the leading function is one of the functions of social intelligence. In particular, the cognitive-evaluative function prevails at the initial stage, while the other two functions create positive conditions for the implementation of the first one. Achieving the goals of cognitive activity to a large extent provide a communicative and valuable function. The reflexive correction function is essentially aimed at actualizing the strengths and qualities compensating for weak and ineffective features and actions. Such functions of social intelligence of the person are manifested in their subordination and interconnection.

Key words: social intelligence, technical intelligence, artistic intelligence, informational intelligence, functions of social intelligence, reflexive and correction function, prognostic function, cognitive-evaluative function, communicative-valuable function.

\section{Вступ}

Деякі дослідники, зокрема Р. Торндайк (Торндайк, 1920), визнали багатовимірну природу соціального інтелекту. Однак в емпіричних дослідженнях соціального інтелекту увага, передусім, приділялася когнітивним аспектам соціального інтелекту, зокрема таким, як соціальне сприймання (Михальчук, 2004; Онуфрієва, 2013). Для того, щоб визначити інші когнітивні характеристики соціального інтелекту, вчені покладалися, як правило, на результати вербальних вимірювальних процедур. Оцінка ж конативних аспектів, пов' язаних із соціальним інтелектом, також здійснювалася з використанням вербальних психодіагностичних методів (наприклад, самозвіту).

У 1980-x pp. М. Форд і М. Тісак (Форд \& Тісак, 1983) зазначали, що для опису та характеристики соціального інтелекту в науковій літературі, як правило, використовується один із трьох критеріїв: 1) здатність до декодування соціальної інформації; 2) ефективність або адаптивність соціальної поведінки (ілюстративні суб’єкт-суб'єктні кон- 
структи є, так би мовити, поведінковими результатами, для експлікації яких потрібні, передусім, соціально-когнітивні навички); 3) будь-яка соціальна навичка, яку можна виміряти.

Дослідження М. Форда й М. Тісака (Форд \& Тісак, 1983) також були спрямовані на визначення характеристик конативної складової соціального інтелекту, що відрізняє його від академічного. У дослідження цих учених було залучено понад 600 студентів вищої школи, у яких вимірювався рівень розвитку соціального інтелекту, а також самооцінка, соціальна компетентність, оцінка студентів із боку однолітків і вчителів тощо. У дослідженнях М. Форда й М. Тісака (Форд \& Тісак, 1983) також було використано тест Х. Хогана, що визначає рівень емпатії особистості, а також рівень розвитку соціальних здатностей, вербальних і математичних здібностей тощо. Вимірювання академічного та соціального інтелекту були зорієнтовані на виявлення рівня значущості окремих чинників. У результаті проведення емпіричних досліджень М. Форд і М. Тісак (Форд \& Тісак, 1983) зробили статистично значущий висновок, що оцінку соціальної компетентності та рівень емпатії особистості набагато легше діагностувати у процесі проведення бесіди з респондентами, ніж під час тестування вербальних і математичних здібностей. Так, М. Форд і М. Тісак (Форд \& Тісак, 1983) припустили, що різниця між їхніми висновками і результатами досліджень, проведених Д. Кітінгом (Кітінг, 1978), має місце внаслідок того, що вони оцінювали, насамперед, конативну, а не когнітивну складову соціального інтелекту.

В емпіричних дослідженнях із метою визначення рівня розвитку соціального інтелекту П. Балтес (Балтес, 1987) застосував авторський «Тест критичної оцінки ситуативної поведінки», а також «Тест визначення рівня розвитку міжособистісної компетентності». Використавши процедуру факторного аналізу, вчений підтвердив припущення щодо зближення або розрізнення конвергентної або 
дискримінантної валідності результатів, отриманих під час вимірювання соціального інтелекту та IQ особистості. Отже, П. Балтес зробив висновок, що конативна складова соціального інтелекту буде більш очевидною в показниках за тестами академічного інтелекту, ніж за умови оцінки вербальної складової соціального інтелекту.

У дослідженнях Л. Брауна і Р. Ентоні (Браун \& Ентоні, 1990) доведено, що моделі соціального й академічного інтелекту - досить різні, але потенційно взаємопов'язані одна з одною. В емпіричних дослідженнях Л. Браун і Р. Ентоні аналізувалися самооцінка й експертна оцінка студентів, на основі чого було зроблено висновки щодо особистісних і поведінкових параметрів соціального інтелекту. За допомогою кластерного аналізу вчені визначили, що в структурі соціального інтелекту старшокласників можна виокремити три базові складові: академічний компонент, компонент зовнішньої оцінки і компонент самооцінки. При цьому дослідники дійшли висновку, що рівень розвитку соціального інтелекту може й не залежати від рівня розвитку академічного компонента. До того ж, розуміння особливостей побудови соціального інтелекту значно відрізняється від власне оцінки соціальних навичок. Учені також виявили, що найкращі результати метод обчислення середнього бала мав у випадку аналізу результатів за самооцінкою та за експертною оцінкою поведінкових аспектів соціального інтелекту, які припускають взаємозв'язок соціальних навичок і поведінки дитини в школі.

Мета статті - визначити базові характеристики соціального інтелекту особистості та з їх урахуванням виокремити функції соціального інтелекту.

\section{Завдання статті}

1. Описати здібності соціального інтелекту в структурі інтелектуальної сфери особистості.

2. Розглянути поняття «інтелект» у широкому та вузькому значеннях. 
3. Схарактеризувати соціальний інтелект як структуру, що вміщує певні здібності особистості до виконання певного виду діяльності.

4. Виокремити основні функції соціального інтелекту.

\section{Методи та методики дослідження}

У роботі використано такі летоди: категоріальний метод, структурно-функціональний метод, аналіз, систематизація, моделювання, узагальнення.

\section{Результати та дискусії}

Як правило, здібності соціального інтелекту вчені описували в структурі «загального» інтелекту або інтелектуальної сфери особистості. Серед моделей інтелекту найяскравіше представлені моделі інтелекту, запропоновані Дж. Гілфордом (Гілфорд, 1956), В. М. Дружиніним (Дружинін, 1998), Л. В. Засєкіною (Засєкіна, 2010), Г. Оллпортом (Оллпорт, 1954), М. Л. Смульсон (Смульсон, 2003), Р. Торндайком (Торндайк, 1920), М. О. Холодною (Холодна, 2002) та ін.

Ми розглядаємо поняття «інтелект» у широкому та вузькому смислах слова. Якщо ми говоримо про широкий сенс інтелекту, йдеться лише про один-єдиний інтелект, про інтелектуальну сферу особистості тощо. У такому розумінні інтелект особистості можна описати як ієрархічну систему, що має декілька рівнів (рис. 1).

Перший рівень - рівень функціонування когніцій, до яких психологи відносять основні психічні процеси (відчуття, сприймання, пам'ять, увага, які, в свою чергу, «контролюють» плин пізнавальної діяльності), а також мислення та уяву, мову і мовлення (Засєкіна, 2010; Михальчук, 2004; Смульсон, 2003 та ін.).

Другий рівень інтелекту - рівень метакогніцій (метакогнітивні інтегратори, «вторинні» психічні процеси), серед яких основні - інтелектуальна ініціація (самостійна постановка задачі), рефлексія, децентрація, інтелекту- 
альні стратегії та уміння (здатності та компетентності), а також метакогнітивний моніторинг, інтуїція, інтелектуальні атитюди (цінності, смисли). Перший і другий рівні інтелекту, на нашу думку, цілковито усвідомлюються особистістю, яка здійснює інтелектуальну діяльність.

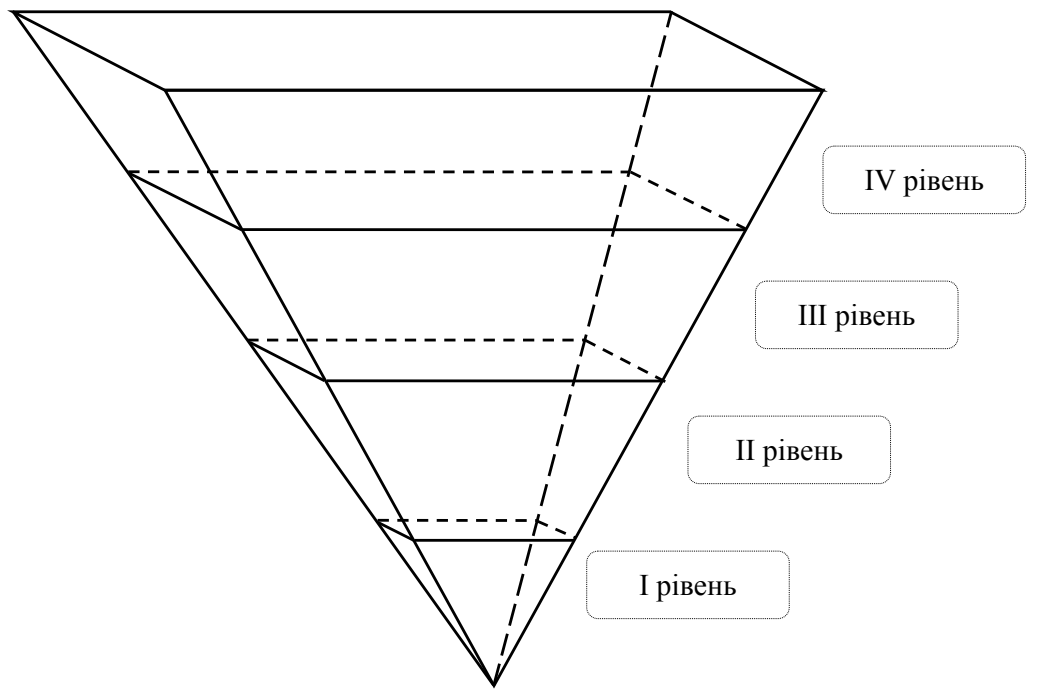

○ I рівень - рівень функціонування когніцій (психічних процесів, мови і мовлення);

○ II рівень - рівень метакогніцій (інтелектуальна ініціація, рефлексія, децентрація, інтелектуальні стратегії й уміння (здатності та компетентності), метакогнітивний моніторинг, інтуїція, інтелектуальні атитюди (цінності, смисли);

- III рівень - рівень ампліфікації характеристик I та II рівнів; здійснення інтелектуальної діяльності на неусвідомлюваному рівні;

○ IV рівень - рівень метаінтелектуальної діяльності (експлікація індивідуальних творчих здобутків особистості).

Puc. 1. Інтелектуальна сфера особистості (розуміння інтелекту в широкому смислі слова)

Tретій рівень інтелекту ампліфікує характеристики як першого, так і другого рівнів, при цьому інтелектуальна 
діяльність здійснюється переважно на неусвідомлюваному рівні, який наближує особистість до використання автоматизованих навичок і вмінь.

Наступний, четвертий, рівень - рівень метаінтелектуальної діяльності, на якому відбувається експлікація творчих здобутків особистості. Саме завдяки цьому четвертому рівню інтелекту людина здатна встановлювати взаємодію не лише з різними об'єктами й іншими людьми, а й зі світом загалом, розширюючи тим самим межі свого інтелекту і розпочинаючи діалог із творчим початком світу.

Якщо йдеться про інтелект у вузькому розумінні цього слова, то ми спираємось, передусім, на модель інтелекту Г. Гарднера (Гарднер, 1983), який в останніх своїх роботах виокремлює сім видів інтелекту: лінгвістичний, музичний, логіко-математичний, просторовий, тілеснокінестетичний, міжособистісний та внутрішньо-особистісний. Подібні моделі інтелекту виокремлені Г. О. Баллом і В. О. Мєдінцевим (Балл \& Мєдінцев, 2011), Н. Кентор і Дж. Кілстромом (Кілстром \& Кентор, 2011). Зокрема, в теоріях Г. О. Балла та В. О. Мєдінцева (Балл \& Мєдінцев, 2011), Н. Кентор і Дж. Кілстрома (Кілстром \& Кентор, 2011) виокремлено технічний інтелект. Також Н. Кентор і Дж. Кілстром (Кілстром \& Кентор, 2011) виокремлюють поетичний і художній інтелект, Г. О. Балл і В. О. Мєдінцев (Балл \& Мєдінцев, 2011) - естетичний інтелект тощо. В основу всіх цих моделей було покладено особливості класифікації здібностей, які автори, як правило, відносять до певних синтезуючих чинників (наприклад, чинник, що визначає здібність людини оперувати кількісними відношеннями, чинник, що детермінує здібність до якісного аналізу та формування категорій і класифікацій, тощо).

Тобто, кожен вид інтелекту вміщує певні здібності особистості до виконання певного виду діяльності. При цьому, наприклад, «лінгвістичний інтелект» автори називають саме «інтелектом», адже це - комплексне інтегральне утворення, що включає окремі здібності до виконання 
певного виду діяльності, а якщо ми говоримо про фахівця цієї сфери діяльності - і компетентності, що, в свою чергу, входитимуть до структури професійної компетентності особистості.

Отже, керуючись вузьким розумінням слова «інтелект», ми виокремлюємо: соціальний інтелект; технічний інтелект; мистецький інтелект; інформаційний інтелект тощо (рис. 2).

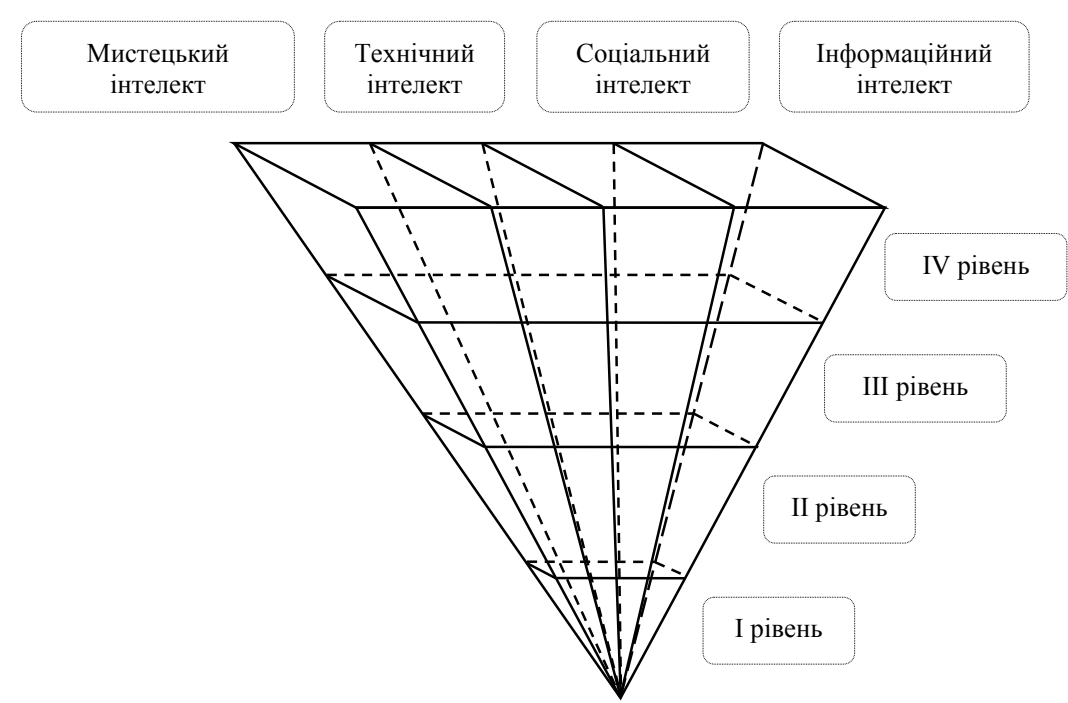

○ І рівень - рівень функціонування когніцій (психічних процесів, мови і мовлення);

○ II рівень - рівень метакогніцій (інтелектуальна ініціація, рефлексія, децентрація, інтелектуальні стратегії й уміння (здатності та компетентності), метакогнітивний моніторинг, інтуїція, інтелектуальні атитюди (цінності, смисли);

○ III рівень - рівень ампліфікації характеристик I та II рівнів; здійснення інтелектуальної діяльності на неусвідомлюваному рівні;

○ IV рівень - рівень метаінтелектуальної діяльності (експлікація індивідуальних творчих здобутків особистості).

Puc. 2. Інтелектуальна сфера особистості (розуміння інтелекту у вузькому смислі слова) 
Технічний інтелект подається в психології як своєрідна система розумових навичок, що дають змогу особистості успішно оволодівати технічними дисциплінами. Результати дослідження студентів технічних і гуманітарних закладів вищої освіти продемонстрували, що базою, на якій формується технічний інтелект, є вміння оперувати просторовими образами, вміння будувати просторові схеми, здатність переводити об'ємне зображення в плоске.

Крім цього, в науковій літературі наголошується, що з формуванням технічного інтелекту тісно пов'язані такі логічні операції, як: здатність визначати категорію, до якої належить поняття, здатність виокремлювати клас об'єкта, вміння визначати суттєву ознаку предмета. Отже, оволодіння логікою, мовою, здатність будувати судження $є$ не додатковою передумовою щодо формування технічного інтелекту, а необхідною умовою його становлення. Природа інтелекту загалом є такою, що далекі за своєю професійною приналежностю розумові навички визначаються певним загальним чинником і розвиваються, формуються лише у системі, як, наприклад, успішне оволодіння математичними операціями. Більше того, однією з ознак сформованості певного виду інтелекту є координованість, узгодженість розвитку різних розумових навичок. Для першої стадії розвитку характерним є послідовний розвиток розумових функцій, послідовна поява однієї навички на базі іншої.

Наприклад, спочатку в дітей розвиваються довготривала пам'ять і увага, а потім починає поліпшуватися логічне мислення. Для інтелекту дорослого характерний одночасний розвиток цілих блоків розумових здібностей. Тому вузькоспеціалізований розвиток тільки одного типу здібностей, що повторює більш ранній спосіб формування інтелекту, може завдати шкоди становленню інтелекту дорослого.

За результатами психологічних досліджень можна виокремити ті якості, що найтісніше пов'язані з успішним формуванням технічного інтелекту. Це - просторові функ- 
ції інтелекту, логічні операції, володіння абстрактною, математичною логікою, вміння представити предмет не у звичному ракурсі, виділити певну часткову площину 3 об’ємного зображення.

До мистецького інтелекту ми відносимо здібності, які багатьма авторами були віднесені до лінгвістичного, поетичного, художнього, танцювального, естетичного інтелекту, адже вважаємо їх здібностями однієї смислової групи. Рівень розвитку мистецького інтелекту неабияким чином визначають такі якісні особливості мислення, як поетичність і образність. Суб’єкти з високим рівнем розвитку мистецького інтелекту вирізняються прагненням до нового і незвіданого, відсутністю страху ризику.

Інфорлаиійний інтелект, на нашу думку, пов'язаний із розвитком здібностей до роботи в складному інформаційному суспільстві, до розуміння інформаційних систем і мереж, прогнозування їх подальшого розвитку та функціонування тощо. Якщо розглядати інформаційні системи як комунікаційну систему, що забезпечує збирання, пошук, обробку та пересилання інформації, то інформаційний інтелект завдяки сукупності здібностей, які входять до його складу, забезпечує обслуговування інформаційних систем. Такими здібностями, передусім, є: здібності, спрямовані на оцінку ситуації (розв'язання задач на розпізнавання образів); здібності, спрямовані на перетворення опису ситуації (розв'язання розрахункових задач, задач на моделювання); здібності, спрямовані на прийняття рішень (у тому числі - й оптимізаційних).

Теоретичне уявлення щодо соціального інтелекту дорослої людини, його структури тощо повинно моделюватися таким чином, ніби сама по собі інтелектуальна діяльність не залежатиме від особливостей мозкової діяльності особистості, її нервової системи та фізіологічних відмінностей організму, з одного боку, і впливу на людину чинників мікро- і макросоціального оточення - з іншого. Це не означає, що функціонування соціального інтелекту 
не залежить від зовнішніх впливів. Навпаки, і стан мозкової активності, й сформованість когніцій, і вміння людини управляти власною метакогнітивною діяльністю, i соціальні чинники (зокрема, чинники навчання та виховання, розвитку тощо) впливають на соціальний інтелект, його функціонування у кожного окремого індивіда. Проте продукти соціального інтелекту, результати його функціонування тощо, породжені інтелектуальною діяльністю, не повинні пояснюватися, передусім, фізіологічними причинами і соціальними впливами. Тому ми приймаємо позицію когнітивістів (Л. В. Засєкіна (Засєкіна, 2010), М. О. Холодна (Холодна, 2002)), згідно з якою необхідною і достатньою логікою для пояснення продуктів інтелектуальної активності може бути, насамперед, логіка професійної діяльності. У такому випадку соціальні репрезентації, що виникають на рівні соціального інтелекту, можна цілком природно тлумачити як результати інтелектуальної діяльності, здійснюваної людиною певної професії. Тому людина, зорієнтована на виконання певного типу професії (професії за типом Людина - Людина, Людина - Техніка, Техніка - Техніка), у якої розвинуті окремі (лінгвістичні, музичні, математичні тощо) здібності, визначально матиме кращий рівень сформованості певного інтелекту, виокремленого в теорії Г. Гарднера (Гарднер, 1983), зокрема, лінгвістичного, поетичного, музичного, технічного тощо.

Отже, функціями соціального інтелекту особистості $є$ розуміння інших людей, пристосування до вимог суспільства, пізнання поведінки соціальних об'єктів, когнітивні та поведінкові функції, функції розуміння дій інших людей i вплив на них, розуміння себе і моделювання поведінки відповідно до своїх потреб, цілей і здібностей, здатність висловлювати спонтанні судження про інших людей, прогнозувати поведінку інших людей, функції пристосування до життєвих ситуацій, розв'язання практичних завдань і ситуацій повсякденного життя, функція соціальної адаптації, функції розв'язання завдань на суб'єкт-суб'єктному рівні, функ- 
ції самоорганізації інтелекту, соціалізації в суспільстві, інтеріоризації соціальних норм і правил, вибір відповідної реакції у міжособистісній взаємодії, а також функції «забезпечення адаптивності в умовах, що постійно змінюються», «формування програми успішної міжособистісної взаємодії», «планування та прогнозування міжособистісних подій соціального середовища», «мотиваційна функція», «функція становлення соціальної компетентності», «саморозвиток», «самопізнання» та «самонавчання» тощо. Усі ці функції можна об'єднати такими узагальненими функціями, як пізнавально-оцінною, комунікативно-ціннісною і рефлексивно-корекційною. На різних етапах виконання діяльності провідною стає одна з функцій соціального інтелекту. Зокрема, пізнавально-оцінна функція переважає на початковому етапі, а інші дві функції створюють позитивні умови для реалізації першої. Досягнення цілей пізнавальної діяльності великою мірою забезпечує комунікативно-ціннісна фрункція. Рефлексивно-корекційна фрункція за своєю суттю спрямована на актуалізацію сильних сторін і якостей та компенсацію слабких і неефективних рис і дій. Виокремлені функції соціального інтелекту особистості виявляються в їх супідрядності й взаємозв'язку.

Подібно до проаналізованих нами функцій пропонує базові функції соціального інтелекту М. О. Лукичова (Лукичова, 2004). Погоджуючись зі змістом описаних вище функцій, авторка виокремлює пізнавальну, комунікативну й оцінну функції соціального інтелекту в процесі здійснення спілкування та міжособистісної взаємодії.

Пізнавальна функція полягає у наголошенні на індивідуальних можливостях для досягнення результатів власної діяльності, у визначенні змісту міжособистісної взаємодії, зумовленої процесом соціалізації. Соціальний інтелект забезпечує обробку інформації, необхідної для прогнозування результатів діяльності. 3 одного боку, людина, отримуючи інформацію щодо характеру діяльності, враховує, аналізує особистісні особливості інших людей. 
3 іншого боку, в процесі обробки отриманої з соціуму інформації відбувається формулювання суджень особистості щодо значення про те, що саме відбувається, якою є мета пізнавальної діяльності, їі результат, до якого слід прагнути. I в тому, і в іншому випадку на першому плані ампліфікуються прояви мисленнєвої активності, пов'язаної з розумінням об'єктно-предметного і суб'єктно-особистісного контекстів ситуації міжособистісної взаємодії.

Реалізація комунікативної функції соціального інтелекту через розуміння об’єктно-предметного і суб'єктноособистісного контекстів ситуації міжособистісної взаємодії дає змогу отримати досить достовірну інформацію про соціальне середовище, а також здійснити зворотний зв'язок у формі ціннісних уявлень про неї. Оцінювальна функція соціального інтелекту, в нашому розумінні, знаходить своє відображення в самопізнанні й усвідомленні переваг і недоліків пізнавальної діяльності, міжособистісного спілкування, що забезпечує внесення змін у процес соціальної взаємодії з іншими людьми. Така функція дозволяє не просто оцінювати навколишню дійсність, а й коригувати взаємодію із соціальним середовищем завдяки розумінню як об'єктно-предметного, так і суб'єктно-особистісного контекстів ситуації міжособистісної взаємодії.

Виокремлені в науковій царині пізнавальна, комунікативна й оцінна функції соціального інтелекту не існують ізольовано, вони взаємопов' язані та взаємозумовлені, відображають специфіку прояву соціального інтелекту завдяки розумінню людиною різних аспектів ситуації міжособистісної взаємодії (об’єктно-предметного і суб’єктноособистісного тощо).

Найповніше в змістовому сенсі кожен із компонентів у представленій структурі соціального інтелекту особистості розкривається через домінуючі функції. Узагальнивши та проаналізувавши наявні в психологічній літературі уявлення щодо ролі соціального інтелекту, які грунтуються на змістових компонентах соціального інтелекту, а також 
ураховуючи його значущість у професійній діяльності, науковці виокремлюють такі функції соціального інтелекту: адекватне розпізнавання, аналіз і передбачення розвитку ситуації професійної взаємодії з урахуванням плинного контексту; емоційне осягнення особистісного та соціально-психологічного контексту ситуації міжособистісної взаємодії; актуалізація особистісних психічних ресурсів; адаптація особистості до постійно змінюваних соціальних умов і контекстів професійної взаємодії; розвиток фахівця як профресіонала та як творчої особистості в міжособистісній взаємодії; комунікативна, спрямована на адекватне, докладне, глибоке тощо спілкування між суб'єктами професійної діяльності. Зазначені функції не лише детермінуються запропонованою структурою соціального інтелекту, а й обгрунтовано iï підтверджують. При цьому слід підкреслити, що всі функції вирізняються особливим аспектом, що наголошує на їх дотичності певним специфічним вимогам професійної діяльності. Загалом взаємозумовленість окреслених функцій відображує провідну роль усіх складових соціального інтелекту особистості.

На думку I. Ф. Баширова (Баширов, 2003), існує сім базових функцій соціального інтелекту:

1) адаптативна, що передбачає адаптивність і адекватність, моделювання програм і планів успішної діяльності та взаємодії (В. М. Куніцина, Н. Кентор, Дж. Гілфорд, М. О’Саллівен);

2) функція адекватного розпізнавання, аналізу та прогнозування розвитку ситуації міжособистісної взаємодії 3 урахуванням зовнішнього мінливого соціального контексту (В. М. Куніциною виокремлено функцію планування міжособистісних подій і прогнозування їхнього розвитку; пізнавально-оцінну функцію, функцію планування й адаптативну функцію виділяли О. С. Михайлова, Н. А. Лужбіна, М. О. Холодна та ін.);

3) функція емоційного «входження» до парадигми особистісного та соціально-психологічного контексту си- 
туації міжособистісної взаємодії, що виокремлюється як необхідна умова реалізації попередньої функції;

4) мотиваційна (В. М. Куніцина). Соціальний інтелект не може ефективно розвиватися поза актуалізацією мотивації саморозвитку, мотивації самовдосконалення, спрямованості особистості на досягнення соціально значущих результатів і продуктивне спілкування з людьми;

5) мобілізаційна (функція актуалізації внутрішніх психічних ресурсів особистості); при цьому соціальний інтелект є засобом ефективного розв'язання особистістю життєвих криз;

6) розвивальна функція (названа В. М. Куніциною як функція саморозвитку, самопізнання, самонавчання, М. О. Холодною - рефлексивно-корекційною функцією, Р. Стернбергом - функцією управління своєю поведінкою);

7) комунікативна (у В. М. Куніциної це - функція набуття особистістю соціальної компетентності; також ця функція імпліцитно представлена в працях Р. Торндайка, Г. Оллпорта, Дж. Гілфорда, М. О’Саллівена, Р. Стернберга, М. О. Холодної та М. О. Лукичової).

\section{Висновки}

Аналіз наукової літератури з окресленої проблеми дав змогу виокремити такі основні функиї соціального інтелекту: прогнозування поведінки інших людей; пізнання поведінки соціальних об'єктів; успішна міжособистісна взаємодія; комунікативна; адаптаційна; керування своєю поведінкою, поведінкова функція тощо; забезпечення продуктивних взаємостосунків індивіда і середовища; розуміння вчинків і дій людей; пізнавально-оцінна; комунікативно-ціннісна; рефлексивно-корекційна; забезпечення адекватності, адаптивності в мінливих умовах соціальної діяльності та взаємодії; формування програми і планів успішної міжособистісної взаємодії в тактичному й стратегічному напрямках із метою розв'язання задач; планування плину міжособистісних подій і прогнозування їх 
розвитку та фрункціонування; мотиваційна функція; мобілізаційна функція; саморозвиток, самопізнання, самонавчання; набуття особистістю соціальної компетентності; пристосування до вимог суспільства; когнітивна функція; здатність висловлювати спонтанні судження про інших людей; розв' язання практичних завдань і ситуацій повсякденного життя; функція самоорганізації інтелекту; функція соціалізації в суспільстві; функція розв'язання завдань на суб'єкт-суб'єктному рівні; функція інтеріоризації соціальних норм і правил; функція актуалізації психічної діяльності; функція вибору відповідної реакції у міжособистісній взаємодії; функція становлення соціальної компетентності; коригувальна функція; оцінна функція.

\section{Література}

Балл Г. О., Мєдінцев В. О. Особистість як індивідуальний модус культури і як інтегративна якість особи. Горизонти освіти. 2011. № 3. C. $7-14$.

Баширов И. Ф. Социальный интеллект как фактор успешности профессиональной деятельности военного психолога: дис. ... канд. психол. наук: 19.00.05. Москва : РГБ, 2003. 153 с.

Дружинин В. Н. Интеллект и продуктивность деятельности: модель «интеллектуального диапазона». Психологический журнал. 1998. Т. 19. № 2. С. 61-71.

Засєкіна Л. В. Профілі значення слова як функція когніції і культури. Наук. записки Острозької акаделії. Серія «Психологія і педагогіка». Острог : Вид-во нац. ун-ту «Острозька академія», 2010. С. 66-75.

Лукичева М. А. Развитие социального интеллекта у студентов - будущих педагогов: дис. ... канд. психол. наук: 19.00.07. Череповец : Череповецкий государственный университет, 2004. 153 с.

Михальчук Н. О. Психологічні засади смислоутворення особистості. Науковий вісник Південноукраїнського державного педагогічного університету іл. К. Д. Уиинського: Збірник наукових праць. Одеca, 2004. № 7. С. 66-71.

Онуфрієва Л. А. Дослідження психологічних детермінант розвитку професійної самосвідомості та особистісної зрілості майбутніх фахівців соціономічних професій. Науковий вісник Миколаївського державного університету ілені В. О. Сухоллинського: зб. наук. праць / За ред. С. Д. Максиленка, Н. О. Свдокилової. Серія «Психологічні науки». Миколаїв : МНУ імені В. О. Сухомлинського, 2013. Т. 2. Вип. 10 (91). С. 227-233. 
Смульсон М. Л. Психологія розвитку інтелекту. Київ : Нора-друк, 2003. $298 \mathrm{c}$.

Холодная М. А. Психология интеллекта. Парадоксы исследования. Санкт-Петербург : Питер, 2002. 272 с.

Allport, G. W. (1954). The nature of prejudice. New York. 165 p.

Baltes, P. B. (1987). Theoretical propositions of life-span developmental psychology, 23, 611-626.

Brown, L. T., \& Anthony, R. G. (1990). Continuing the search for social intelligence. Personality and Individual Differences, 11, 463-470.

Ford, M. E., \& Tisak, M. S. (1983). A future search of social intelligence. Journal of Educational Psychology. 75 (2), 196-207.

Gardner, H. (1983). Frames of mind: The theory of multiple intelligences. London : Heinemann. 178 p.

Guilford, J. P. (1956). The structure of intellect. New York : Psychol Bull, 63-99.

Keating, D. K. (1978). A search for social intelligence. Journal of Educational Psychology, 70, 218-233.

Kihlstrom, J. F., \& Cantor, N. (2011). Social Intelligence. Retrieved from http://istsocrates.berkeley.edu/ kihlstrom/social_intelligence. htm.

Onufriieva, L. A. (2017). The Psychology of Professional Realization of a Future Specialist's Personality: Theoretical and Methodological Aspect. Monograph. Rzeszów : BonusLiber. $194 \mathrm{~s}$.

Thorndike, R. L. (1920). Intelligence and its uses. Harper's Magazine, 227-235.

\section{References}

Ball, H. O., \& Miedintsev, V. O. (2011). Osobystist yak indyvidualnyi modus kultury i yak intehratyvna yakist osoby [Personality as the individual mode of culture and as the integrative quality of a person]. Horyzonty osvity - Horizons of education, 3, 7-14 [in Ukrainian].

Bashirov, I. F. (2003). Social'nyj intellekt kak faktor uspeshnosti professional'noj dejatel'nosti voennogo psihologa [Social intelligence as a factor of the success of the professional activity of the military psychologist]. Candidate's thesis. Moskva : RSL [in Russian].

Druzhinin, V. N. (1998). Intellekt i produktivnost' dejatel'nosti: model' «intellektual'nogo diapazona» [Intellect and productivity of the activity: the model of «intellectual range»]. Psihologicheskij zhurnalPsychological Journal, 19 (2), 61-71 [in Russian].

Zasiekina, L. V. (2010). Profili znachennia slova yak funktsiia kohnitsii i kultury [Profiles of the word meaning as a function of cognition and culture]. Nauk. zapysky Ostrozkoi akademii. Seriia «Psykholohiia $i$ pedahohika» - Scientific notes of Ostroh Academy. Series "Psycho- 
logy and Pedagogy». Ostroh : Vyd-vo nats. un-tu «Ostrozka akademiia», 66-75 [in Ukrainian].

Lukicheva, M. A. (2004). Razvitie social'nogo intellekta u studentov - budushchih pedagogov [The development of social intelligence of students - future teachers]. Candidate's thesis. Cherepovec : Cherepoveckij gosudarstvennyj universitet [in Russian].

Mykhalchuk, N. O. (2004). Psykholohichni zasady smysloutvorennia osobystosti [Psychological foundations of personality making]. Naukovyi visnyk Pivdennoukrainskoho derzhavnoho pedahohichnoho universytetu im. K. D. Ushynskoho: Zbirnyk naukovykh prats - Scientific Newsletter of the South Ukrainian State Pedagogical University named after K. D. Ushynskyi: Collection of research papers, 7, 66-71. Odesa [in Ukrainian].

Onufriieva, L. A. (2013). Doslidzhennia psykholohichnykh determinant rozvytku profesiinoi samosvidomosti ta osobystisnoi zrilosti maibutnikh fakhivtsiv sotsionomichnykh profesii [The study on the psychological determinants of the development of professional selfconsciousness and personal maturity of future specialists of socionomic professions]. S. D. Maksymenko, N. O. Yevdokymova (Eds.). Naukovyi visnyk Mykolaivskoho derzhavnoho universytetu imeni V.O. Sukhomlynskoho: zb. nauk. prats - Scientific Newsletter of Mykolaiv State University named after V. O. Sukhomlynskyi: Collection of research papers. Series «Psychological Sciences», 2, 10 (91), 227-233. Mykolaiv : MNU imeni V. O. Sukhomlynskoho [in Ukrainian].

Smulson, M. L. (2003). Psykholohiia rozvytku intelektu [Psychology of the intelligence development]. Kyiv : Nora-druk [in Ukrainian].

Holodnaja, M. A. (2002). Psihologija intellekta. Paradoksy issledovanija [The psychology of intelligence. Paradoxes of the research]. SanktPeterburg : Piter [in Russian].

Allport, G. W. (1954). The nature of prejudice. New York. $165 \mathrm{p}$.

Baltes, P. B. (1987). Theoretical propositions of life-span developmental psychology, 23, 611-626.

Brown, L. T., \& Anthony, R. G. (1990). Continuing the search for social intelligence. Personality and Individual Differences, 11, 463-470.

Ford, M. E., \& Tisak, M. S. (1983). A future search of social intelligence. Journal of Educational Psychology. 75 (2), 196-207.

Gardner, H. (1983). Frames of mind: The theory of multiple intelligences. London : Heinemann. $178 \mathrm{p}$.

Guilford, J. P. (1956). The structure of intellect. New York : Psychol Bull, $63-99$.

Keating, D. K. (1978). A search for social intelligence. Journal of Educational Psychology, 70, 218-233.

Kihlstrom, J. F., \& Cantor, N. (2011). Social Intelligence. Retrieved from http://istsocrates.berkeley.edu/ kihlstrom/social_intelligence.htm. 
Onufriieva, L. A. (2017). The Psychology of Professional Realization of a Future Specialist's Personality: Theoretical and Methodological Aspect. Rzeszów : BonusLiber.

Thorndike, R. L. (1920). Intelligence and its uses. Harper's Magazine, 227-235.

Івашкевич Едуард, Онуфрієва Ліана. Природа соціального інтелекту особистості та його базові функції

\section{АНОТАЦІЯ}

У статті зазначено, що соціальний інтелект у психології розглядається як здатність людини правильно розуміти свою поведінку і поведінку інших людей у суспільстві. Ця здатність $є$ вельми необхідною людині для ефективної міжособистісної взаємодії та успішної соціальної адаптації. Соціальний інтелект реалізує функціонування пізнавальних процесів, пов'язаних із відображенням людини як партнера по спілкуванню та діяльності. Основна функція соціального інтелекту - прогнозування поведінки інших.

Наголошено, що кожен вид інтелекту вмішує певні здібності особистості до виконання певного виду діяльності. При цьому, наприклад, "лінгвістичний інтелект» автори називають саме «інтелектом», адже це - комплексне інтегральне утворення, що включає окремі здібності до виконання певного виду діяльності, а якщо ми говоримо про фахівця цієї сфери діяльності - і компетентності, що, в свою чергу, входитимуть до структури професійної компетентності особистосmi. Керуючись вузьким розумінням поняття «інтелект», у статmі виокремлюються: соціальний інтелект; технічний інтелект; мистецький інтелект; інформаційний інтелект тощо.

Функціями соціального інтелекту особистості є розуміння інших людей, пристосування до вимог суспільства, пізнання поведінки соціальних об'єктів, когнітивні та поведінкові функції, функції розуміння дій інших людей і вплив на них, розуміння себе і моделювання поведінки відповідно до своїх потреб, цілей і здібностей, здатність висловлювати спонтанні судження про інших людей, прогнозувати поведінку інших людей, функції пристосування до життєвих ситуацій, розв'язання практичних завдань і ситуацій повсякденного життя, функція соціальної адаптації, функції розв'язувати завдання на суб'єкт-суб'єктному рівні, функції самоорганізації інтелекту, соціалізації в суспільстві, інтеріоризації соціальних норм і правил, вибір відповідної реакції у міжособистісній взаємодії, а також функції «забезпечення адаптивності в умовах, що постійно змінюються», "формування програми успішної 
міжособистісної взаємодії», "планування та прогнозування міжособистісних подій соціального середовища», "мотиваційна функція», "функція становлення соціальної компетентності», "саморозвиток», "самопізнання» та «самонавчання» тощо. Усі ці функції можна об'єднати такими узагальненими функціями, як пізнавально-оцінною, комунікативно-ціннісною і рефлексивно-корекційною. На різних етапах виконання діяльності провідною стає одна з функцій соціального інтелекту. Зокрема, пізнавально-оцінна функція переважає на початковому етапі, а інші дві функції створюють позитивні умови для реалізації першої. Досягнення цілей пізнавальної діяльності великою мірою забезпечує комунікативно-ціннісна функція. Рефлексивно-корекційна функція за своєю суттю спрямована на актуалізацію сильних сторін і якостей та компенсацію слабких і неефективних рис і дій. Зазначено, що виокремлені функиії соціального інтелекту особистості виявляються в їх супідрядності й взаємозв'язку.

Ключові слова: соціальний інтелект, технічний інтелект, мистецький інтелект, інформаційний інтелект, функції соціального інтелекту, рефлексивно-корекційна функція, прогнозувальна функція, пізнавально-оцінна функція, комунікативно-ціннісна функція.

\section{Ивашкевич Эдуард, Онуфриева Лиана. Природа социального интел- лекта личности и его базовые функции}

\section{АННОТАЦИЯ}

В статье указано, что социальный интеллект в психологии рассматривается как способность человека правильно понимать свое поведение и поведение других людей в обществе. Эта способность является весьма необходимой для человека с иелью осуществления эффективного межличностного взаимодействия и успешной социальной адаптации. Социальный интеллект реализует функционирование познавательных процессов, связанных с отражением человека как партнера по общению и деятельности. Основная функция социального интеллекта - прогнозирование поведения других.

Отмечено, что каждый вид интеллекта вмещает определенные способности личности к выполнению определенного вида деятельности. При этом, например, "лингвистический интеллект» авторы называют именно "интеллектом", ведь это - комплексное интегральное образование, включающее отдельные способности к выполнению определенного вида деятельности, а если мы говорим о специалисте данной сореры деятельности - и компетентности, которые, в свою 
очередь, будут входить в структуру профессиональной компетентности личности. Руководствуясь узким пониманием понятия «интеллект", в статье выделяются: социальный интеллект; технический интеллект; художественный интеллект; информационный интеллект.

Функциями социального интеллекта личности являются понимание других людей, приспособление к требованиям общества, познание поведения социальных объектов, когнитивные и поведенческие функции, функции понимания действий других людей и влияние на них, понимания себя и моделирования поведения в соответствии со своими потребностями, целями и способностями, способность выражать спонтанные суждения о других людях, прогнозировать поведение других людей, функции приспособления к жизненным ситуациям, решения практических задач и ситуаций повседневной жизни, функция социальной адаптации, функции решать задачи на субъект-субъектному уровне, функции самоорганизации интеллекта, социализации в обществе, интериоризации социальных норм и правил, выбор соответствующей реакции в межличностном взаимодействии, а также функции "обеспечение адаптивности в постоянно изменяющихся условиях", "формирование программы успешного межличностного взаимодействия», «планирование и прогнозирование межличностных событий социальной среды», "мотивационная функция», "функция становления социальной компетентности», "саморазвитие», "самопознание» и "самообучение». Все эти функции можно объединить такими обобщенными функциями, как познавательно-оценочная, коммуникативно-ценностная и рефлексивно-коррекционная. На разных этапах выполнения деятельности ведущей становится одна из функций социального интеллекта. В частности, познавательно-оценочная функция преобладает на начальном этапе, а другие две функции создают положительные условия для реализации первой. Достижение целей познавательной деятельности во многом обеспечивает коммуникативно-ценностная функция. Рефлексивно-коррекционная функция по своей сути направлена на актуализацию сильных сторон и качеств, компенсацию слабых и неэфрективных характеристик и действий. Отмечено, что выделенные функции социального интеллекта личности проявляются в их соподчинении и взаимосвязи.

Ключевые слова: социальный интеллект, технический интеллект, художественный интеллект, информационный интеллект, функции социального интеллекта, рефлексивно-коррекционная функция, прогностическая функция, познавательно-оченочная функция, коммуникативно-ценностная функция. 